\title{
Apresentação do Vol. 1, N. 1 da Revista do Departamento de Psicologia - UFF, 1989
}

Regina D. B. de Barros Chefe do Departamento de Psicologia/UFF

\author{
“É necessário apresentar estes ensaios? Acaso não se \\ apresentam eles mesmos? Apresentá-los será representá-los, \\ pô-los em representação."
}

Lyotard, J. F.

A Revista estava pronta. Alguns anos haviam se passado desde as primeiras idéias de se criar um instrumento que pudesse fazer circular fragmentos do nosso pensar.

Bem sabíamos que a Universidade não é um "espaço independente, consagrado à elaboração e transmissão do saber". Afinal, uma sociedade como a nossa, só tem subsistido porque violenta a integração de suas próprias funções. Ela não suporta, portanto, uma zona de livre conhecimento e expressão.

Buscávamos sua democratização, mas entendíamos que este caminho passava pela construção de ferramentas, de obras, que permitissem a compreensão crítica da realidade sob todas as suas formas e a liberação do poder de expressão.

A idéia da revista nos pareceu uma possibilidade de intervir. Intervir no espaço social que ultrapassa os muros da Universidade. Intervir nos fechados e isolados discursos da "ciência" academizada que buscam apenas o referendo narcísico de suas hipóteses. Intervir sobre nós mesmos, buscando trazer nossa produção para discussão coletiva.

A Revista é, assim, mais do que uma reunião de artigos; é uma proposta de trabalho, um caminho. Convidamos todos os leitores a virem percorrê-lo conosco. 